\title{
Dynamic Modeling and Simulation of an Isolated Hybrid Power System in a Rural Area of China
}

\author{
Bojian Jiang $(\mathbb{D})$ and M. Tariq Iqbal (iD \\ Faculty of Engineering and Applied Science, Memorial University of Newfoundland, St. John's, NL, Canada \\ Correspondence should be addressed to Bojian Jiang; bjiang@mun.ca
}

Received 18 January 2018; Revised 23 February 2018; Accepted 27 March 2018; Published 3 June 2018

Academic Editor: Sundaram Senthilarasu

Copyright (C) 2018 Bojian Jiang and M. Tariq Iqbal. This is an open access article distributed under the Creative Commons Attribution License, which permits unrestricted use, distribution, and reproduction in any medium, provided the original work is properly cited.

\begin{abstract}
In some rural areas in the northwest of China, people are suffering from not only the voltage drop due to long distance transmission but also the power outages due to remoteness and poorly maintained grid. In recent few years, the price of solar energy has been reduced drastically every year in China due to the government policy on renewable energy. In the near future, isolated hybrid power systems for home use could be affordable and used by residences in these rural areas. Thus, it is necessary to design a hybrid power system based on local load and weather condition to check system feasibility and expected performance. It includes load simulation, system sizing, and dynamic system modeling and simulation. This paper firstly introduces current development of renewable energy in China and then goes through the sizing, modeling, and simulation of the system design for a typical remote home in China and finally discusses the system's availability based on the simulation results. In this paper, the NASA website is the source for weather data, and BEopt is used to generate load data. During system modeling, the MPPT algorithm is much simpler designed than the complex incremental method. A soft starter is adopted with the diesel generator for stability. The charge controller of the battery storage provides external command to the MPPT and diesel PID controller to prevent the battery storage from overcharging. The rms value of the fundamental load voltage is used in the voltage control loop of the inverter.
\end{abstract}

\section{Introduction}

In some rural areas in Qinghai province located in the northwest of China, people have to put up with the voltage drop over $5 \%$ of the rated voltage due to long distance transmission. Besides, due to the lowest load priority of these areas, the power stability cannot be strictly maintained. Fortunately, these areas have abundant renewable energy resources, especially solar and wind energy. According to [1], in Tibet and southeast of the Qingzang Altiplano (including Qinghai province), annual irradiation amount is about 6600$8500 \mathrm{MJ} / \mathrm{m}^{2}$. The annual average wind density in Qinghai province is above $50 \mathrm{~W} / \mathrm{m}^{2}$ [2]. These data show great potentials to develop hybrid power systems in rural areas in Qinghai province. Due to the impulsive Chinese government policies for renewable energy, like reductions in sales and taxes, Chinese installed renewable energy in 2016 took the largest capacity of world, which can be seen from Figure 1 [3].
This fast development decreases the price of the renewable energy. The levelized cost of solar PV and onshore wind power are $0.075-0.155 \mathrm{USD} / \mathrm{kwh}$ and $0.05-0.07 \mathrm{USD} / \mathrm{kwh}$, respectively, in China [2]. If the policies continue existing, the cost of solar and wind power will constantly decrease. Thus, in the near future, isolated hybrid power systems incorporating renewable and traditional energy could be purchased by the users in the remote areas of Qinghai province. However, system economics must be achieved based on reliability (ability to meet the load). They need to size the system based on hourly renewable resource data and load data of the selected site. Besides that, the dynamic modeling and simulation of the system are needed to check system dynamics to see whether the system can operate steadily under the drastic changes of renewable resources and load. A number of such studies have been done for other parts of the world [4-6], and they all indicate a much better supply condition with an addition of hybrid power system. 


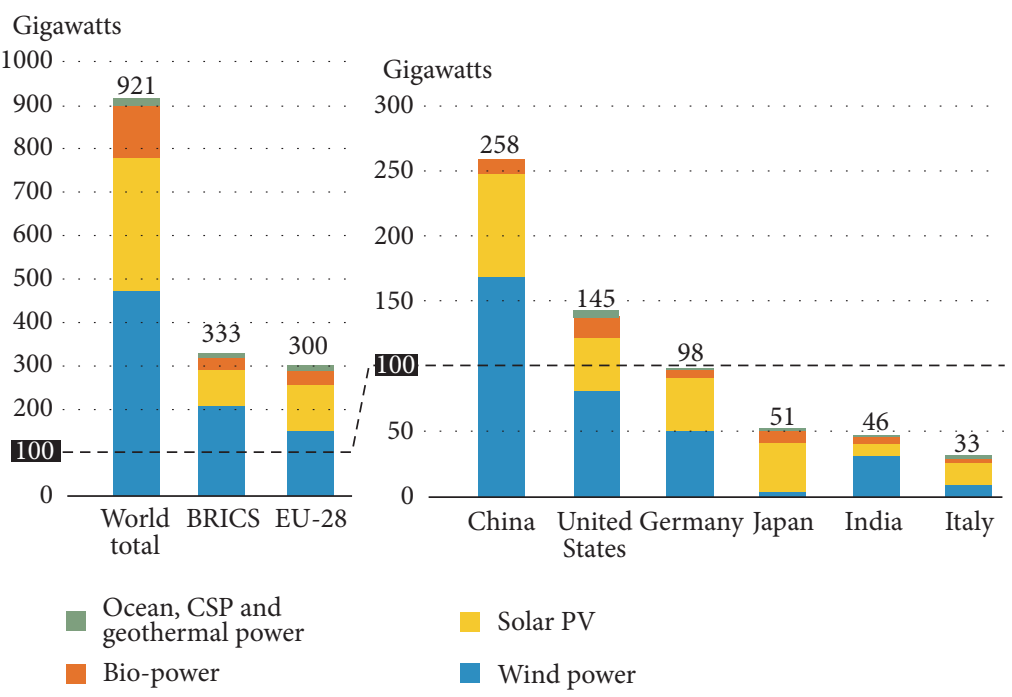

FIGURE 1: Renewable power capacities in the world, BRICS, EU-28, and top 6 countries [3].

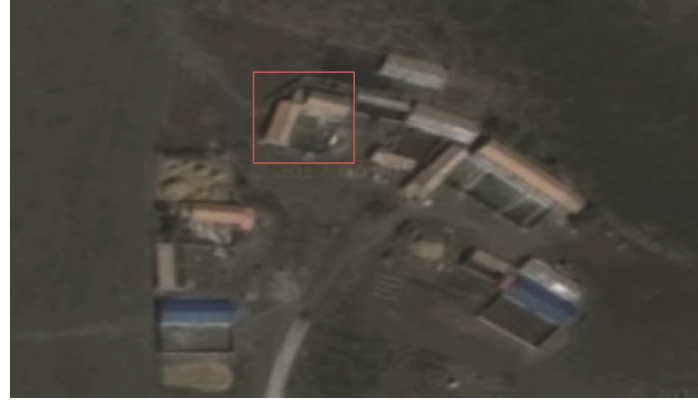

FIGURE 2: Site topography.

\section{System Sizing}

\subsection{Site Location and Renewable Resource}

2.1.1. Site Location. The selected site is located at a remote area in Qinghai province, with coordinates of $37^{\circ} 50^{\prime} \mathrm{N}$ and $101^{\circ} 58 \mathrm{E}$. The site's building (enclosed in the red rectangular) and peripheral topography are shown in Figure 2.

It can be seen from Figure 2 that there are no obstacles such as hills, forests, or large buildings around the site. Less turbulence and shade affect the power output of wind turbines and PV arrays. Thus, more power can be harvested from wind turbines and PV arrays.

2.1.2. Renewable Resources of the Site. The location of the site determines the site's renewable resource and temperature. The renewable resources are the power source for renewable power generation, and the power output of PV arrays is highly related to temperature. These data can be found on NASA's website by inputting the coordination of the site. The details of the wind and solar resources and temperature of the site are shown in Figures 3, 4, and 5, respectively.

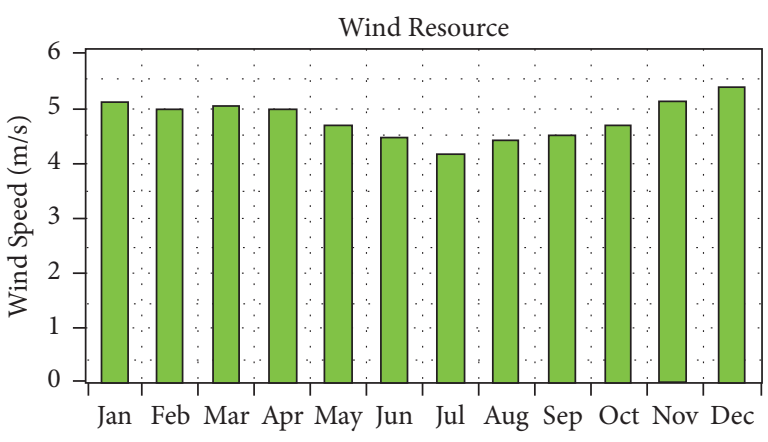

FIGURE 3: Site wind resource.

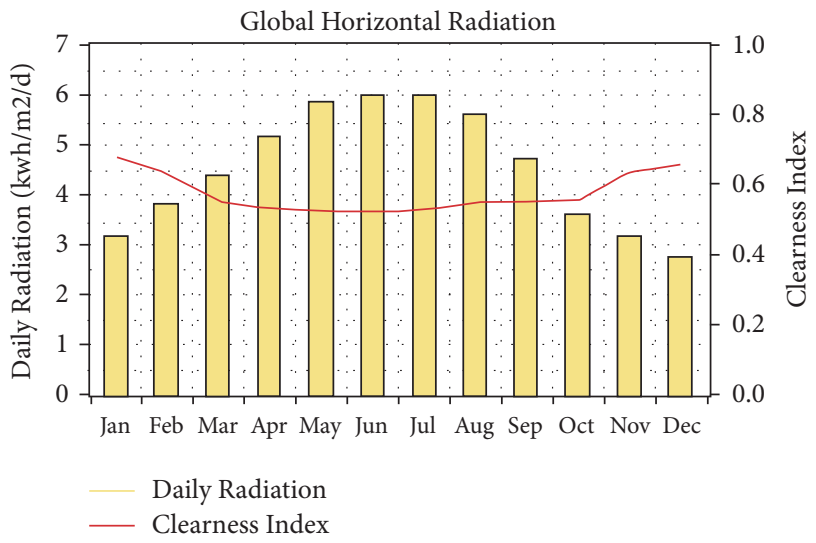

FIGURE 4: Site solar resource.

Figure 3 shows that the average wind speed in each month is evenly distributed around $5 \mathrm{~m} / \mathrm{s}$. This means that a wind turbine could constantly generate high power throughout a year. Figure 4 shows that the average solar resource is $4.51 \mathrm{kwh} / \mathrm{m}^{2} /$ day, and Figure 5 shows that the monthly average ambient temperature is below $15^{\circ} \mathrm{C}$. These are beneficial 


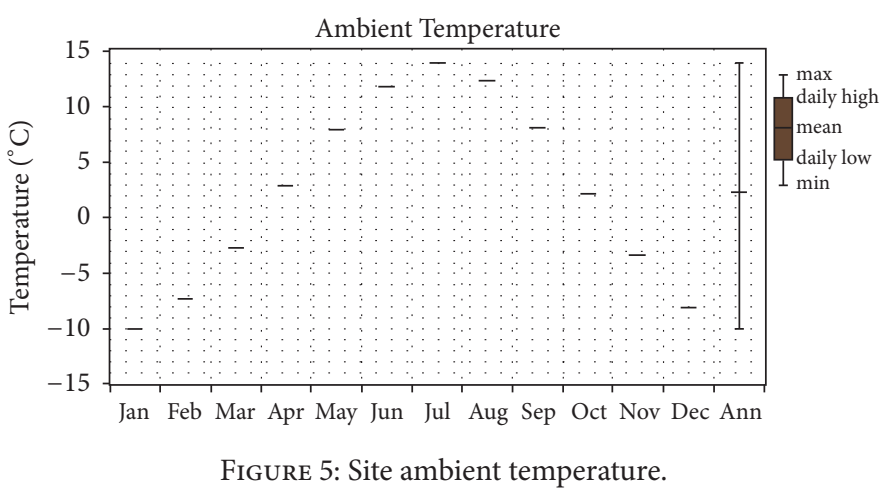

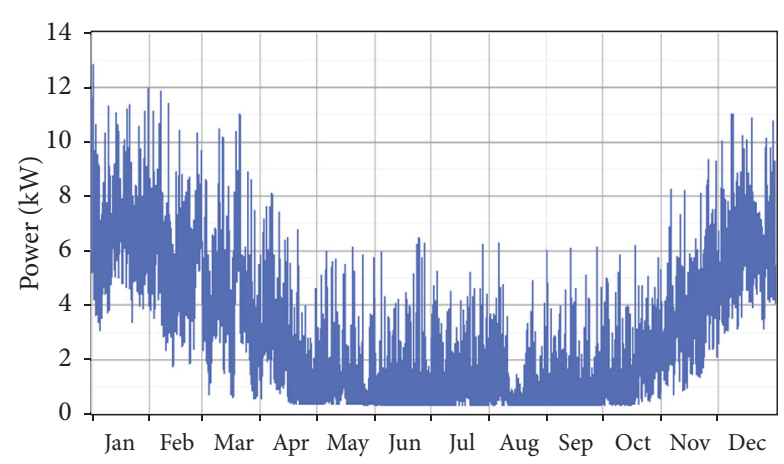

FIgURE 6: Hourly load data.

for high power output of PV arrays. Thus, a large amount of energy can be harvested by reasonable arrangement of the PV array and wind turbine, avoiding shades and turbulence for the PV array and wind turbine.

2.2. Hourly Load Data Generation. Since hourly load data is unavailable in China, specific software, such as Energy3D or BEopt, is needed. Thermal load (load for cooling and heating) takes a large percentage of the total load, so the precision of the weather data and the insulation value of the house model are important during load generation. Since site's weather data and detailed insulation values of the house are available in BEopt, it is chosen to build the house model. The house model is designed based on the architecture shown in Figure 2. The generated hourly load data is shown in Figure 6.

2.3. Deferrable Load Generation. Since there are no water pipes in these areas, water pumping is needed. This deferrable load represents the load for water pumping, since the water pumping sometimes can be substituted by hand lifting. Amount of water needed for a family with 3 people each day is $0.852 \mathrm{~m}^{3}$, and the total dynamic head and energy needed for water pumping are calculated as follows:

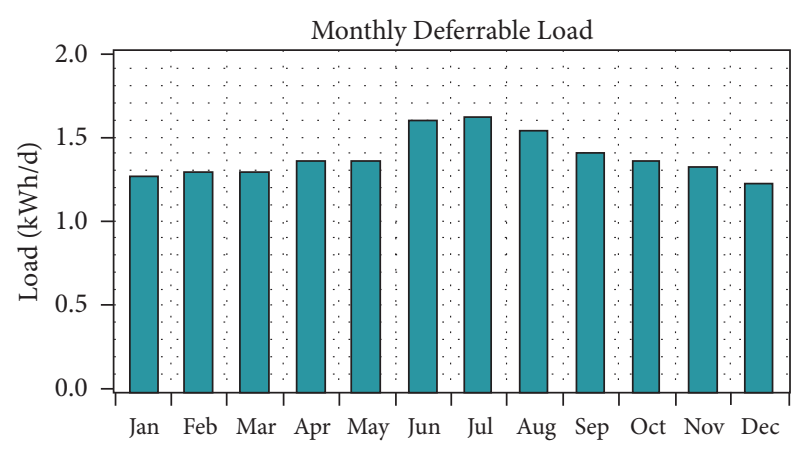

Figure 7: Monthly deferrable load data.

$$
\begin{aligned}
H_{\mathrm{TDH}}= & \text { Vertical Head }+ \text { Friction Loss } \\
& + \text { Tank Pressure } \\
P E= & \frac{\rho m g H_{\mathrm{TDH}}}{0.7 \eta_{\mathrm{PV}} \eta_{\mathrm{MPPT}} \eta_{\mathrm{BB}} \eta_{\mathrm{PM}}},
\end{aligned}
$$

where the friction loss is $20 \%$ of the total length of the horizontal sections and pipe elbows, tank pressure is the height of the tank, $H_{\mathrm{TDH}}$ is the total dynamic head, $\eta_{\mathrm{PV}}$ is the efficiency for the PV array, $\eta_{\text {MPPT }}$ is the efficiency for the MPPT, $\eta_{\mathrm{BB}}$ is the round-trip conversion efficiency for the battery bank, and $\eta_{\mathrm{PM}}$ is the inside pipe loss. The resulting monthly data is shown in Figure 7.

2.4. System Optimization. This process is done in Homer 2.68. This software is used to design hybrid power systems and size them on hourly basis.

2.4.1. System Block Diagram. The designed system is a DC coupled system. This is easier to control and is more robust than AC coupled systems. The system includes a wind turbine, PV panels, a diesel generator, inverter, batteries, DC deferrable load, and AC prime load. The wind turbine and PV array transfer wind power and solar power into electricity and then charge the battery storage and supply the load.

The diesel generator generates power when power generated by the PV array and wind turbine cannot meet the load. 


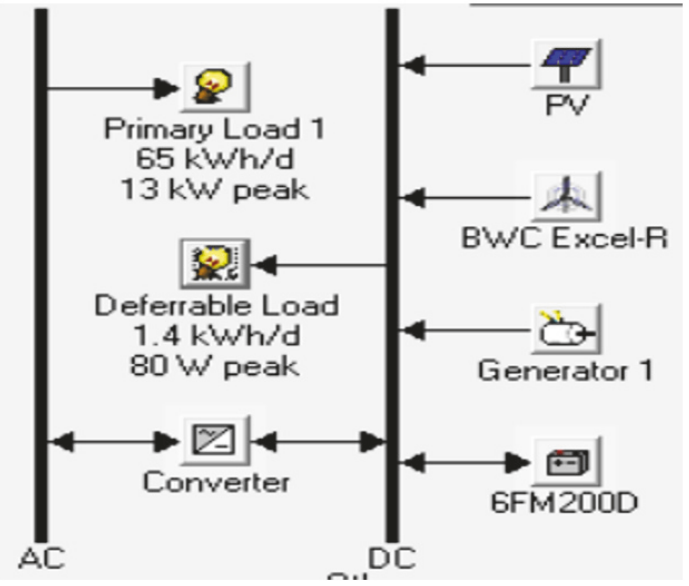

FIgure 8: System sketch.

\begin{tabular}{|c|c|c|c|c|c|c|c|c|c|c|c|c|c|}
\hline Sensitivity Result: & is Opt & tim & 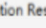 & sults & & & & & & & & & \\
\hline Double click on a & a syster & $m$ bel & ow for & & & & & & & & & ategoriz & Qveral. \\
\hline PAc日目 & & XLR & $\begin{array}{l}\text { Label } \\
\text { (KW) }\end{array}$ & 6FM20 & $\begin{array}{l}\text { Conv. } \\
(\mathrm{kW})\end{array}$ & \begin{tabular}{|l|} 
Disp. \\
Strgy
\end{tabular} & $\begin{array}{l}\text { Initiol } \\
\text { Capital }\end{array}$ & $\begin{array}{l}\text { Operating } \\
\text { Cost }(\mathrm{S} / \mathrm{yr})\end{array}$ & $\begin{array}{l}\text { Total } \\
\text { NPC }\end{array}$ & \begin{tabular}{|c|} 
COE \\
$3 / \mathrm{kW}$ \\
\end{tabular} & $\begin{array}{l}\text { Ren. } \\
\text { Frac. }\end{array}$ & $\begin{array}{c}\text { Diesel } \\
\text { (I) }\end{array}$ & $\begin{array}{l}\text { Label } \\
\text { (hrs) }\end{array}$ \\
\hline 的园 & 13... & & 8 & 20 & 15 & $\propto c$ & $\$ 28.595$ & 10,187 & $\$ 158.824$ & 0.509 & 0.62 & 4.666 & 1,867 \\
\hline ○붐 & 13... & & 8 & 20 & 15 & $\propto c$ & $\$ 27,935$ & 10,250 & S 158,968 & 0.509 & 0.60 & 4726 & 1,893 \\
\hline 口曰四 & 13.. & & 8 & 24 & 15 & $c c$ & $\$ 30,195$ & 10,074 & S 158,977 & 0.510 & 0.62 & 4537 & 1,811 \\
\hline o日园 & 13... & & 8 & 24 & 15 & $c c$ & $\$ 29,535$ & 10,140 & S 159,162 & 0.510 & 0.61 & 4,600 & 1,831 \\
\hline ○曰园 & 13... & & 8 & 16 & 15 & $\propto c$ & $\$ 26,995$ & 10,354 & S 159,357 & 0.511 & 0.61 & 4881 & 1,969 \\
\hline ○田 & 13... & & 8 & 16 & 15 & $c c$ & $\$ 26,335$ & 10,421 & $\$ 159,545$ & 0.511 & 0.59 & 4,934 & 1,989 \\
\hline 0붐 & 13... & & 8 & 28 & 15 & $c c$ & $\$ 31,795$ & 10,003 & S 159,665 & 0.512 & 0.63 & 4,466 & 1,779 \\
\hline 6붕 & 10... & 1 & 7 & 20 & 15 & $c c$ & $\$ 50,995$ & 8,513 & S 159,818 & 0.512 & 0.73 & 3,439 & 1,510 \\
\hline 0임 & 11.... & 1 & 7 & 16 & 15 & cc & $\$ 50,055$ & 8,591 & S 159,876 & 0.512 & 0.73 & 3,555 & 1,573 \\
\hline 6国 & 11.... & 1 & 7 & 20 & 15 & $\propto c$ & $\$ 51,655$ & 8.457 & S 159,890 & 0.513 & 0.74 & 3,382 & 1,482 \\
\hline 0日四 & 13... & & 7 & 48 & 15 & $c c$ & $\$ 39,495$ & 9,422 & S 159,944 & 0.513 & 0.65 & 3,989 & 1,736 \\
\hline 口웝 & 10... & 1 & 7 & 16 & 15 & $c c$ & $\$ 49,395$ & 8,648 & S 159,950 & 0.513 & 0.72 & 3.617 & 1,604 \\
\hline Oe日 & 13... & & 8 & 28 & 15 & $c c$ & $\$ 31,135$ & 10,084 & S 160,038 & 0.513 & 0.61 & 4,541 & 1,806 \\
\hline 6영 & 9.92 & 1 & 7 & 20 & 15 & $c c$ & $\$ 50,335$ & 8.593 & S 160,188 & 0.513 & 0.72 & 3.515 & 1,545 \\
\hline 0붕 & 9.92 & 1 & ? & 16 & 15 & $\propto c$ & $\$ 48,735$ & 8,719 & S 160,188 & 0.513 & 0.71 & 3.600 & 1,630 \\
\hline 㩆 & 9.30 & 1 & 7 & 16 & 15 & $c c$ & $\$ 48,075$ & 8,788 & S 160,414 & 0.514 & 0.70 & 3,750 & 1,663 \\
\hline O国 & 13... & & 8 & 32 & 15 & $c c$ & $\$ 33,395$ & 9.941 & S 160,480 & 0.514 & 0.63 & 4.394 & 1,748 \\
\hline 8の四 & 9.30 & 1 & 7 & 20 & 15 & $c c$ & $\$ 49,675$ & 8,668 & S 160,485 & 0.514 & 0.70 & 3.611 & 1,595 \\
\hline 0붕 & 9.92 & 1 & 7 & 12 & 15 & $c c$ & $\$ 47,135$ & 8,867 & S 160,485 & 0.514 & 0.70 & 3,907 & 1,759 \\
\hline O甲⿴囗大 & 10... & 1 & 7 & 24 & 15 & $\propto c$ & \$ 52,595 & 8,441 & S 160,494 & 0.514 & 0.74 & 3,334 & 1,461 \\
\hline 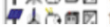 & 11... & 1 & 7 & 24 & 15 & cc & $\$ 53255$ & 8396 & S 160582 & 0.515 & 0.75 & 3275 & 1.434 \\
\hline
\end{tabular}

FIGURE 9: System sizing result.

The AC primary load and DC deferrable load represent the power for the house and water pumping. The system sketch is shown in Figure 8.

2.4.2. System Sizing. In this process, Homer checks whether the system can fully supply the load in each hour. Then it compares the economics among all available systems. The final sizing result is shown in Figure 9.

The result shows that the 1st and 8th systems are the two most economic systems; the 1st one is more economic than the 8 th one. Figure 6 shows that the load in winter is much higher than that in summer. Figure 3 shows that the wind speed in winter is higher than that in summer, and Figure 4 shows that the solar irradiance is much lower in winter. Thus, the 8th system could be better than the 1st system, since the 8th one includes a wind turbine, which can provide enough instant power to the load conserving the diesel usage. However, the 8 th system has $2546 \mathrm{kWh}$ more excessive electricity generated in a year than the 1st system. Hence, excessive electricity could lead to losses and this energy should be decreased as much as possible. In conclusion, the 1st system is chosen because of the better economics and less excess electricity. The system uses one $13 \mathrm{~kW}$ PV array, 20 batteries, one $15 \mathrm{~kW}$ inverter, and one backup generator.

\section{Dynamic Modeling and Simulation of the Designed System}

Dynamic modeling and simulation are to check whether the system can maintain a steady state during severe system changes. The overall system model is shown in Figure 10.

In the system, the PV array transforms the solar irradiance into electrical power, and then this power is boosted up by Maximum Power Point Tracker. The power from PV array along with the power from diesel generator charges the batteries and supplies the AC load through an inverter. The detailed model of each subsystem is described below.

3.1. PV Array. The PV array transforms the solar radiation through photovoltaic effect of each solar cell.

Each solar module consists of solar cells connected in series, and the PV array consists of solar modules connected in series and parallel. Since there are 44 solar modules connected in series and parallels, 44 subsystems of solar modules suggested by Brigitte [7] are needed in the model of the solar array. As a result, the simulation speed will become slow. Thus, the solar array model from [8] is used, which is shown in Figure 12. Its mathematic equations are shown as follows [8]:

$$
\begin{aligned}
I_{d} & =I_{o}\left[\exp \left(\frac{V_{d}}{V_{T}}\right)-1\right] \\
V_{T} & =\frac{k T}{q} \times n I \times N \text { cell } \\
V_{\mathrm{OCT}} & =V_{\mathrm{OC}}\left(1+\beta_{\mathrm{Voc}}(T-25)\right) \\
I_{\mathrm{SCT}} & =I_{\mathrm{SC}}\left(1+\alpha_{\mathrm{Isc}}(T-25)\right) \\
V_{d} & =V_{\mathrm{PV}}+R_{\mathrm{s} \_ \text {array }} I_{\mathrm{PV}} \\
I_{\mathrm{PV}} & =I_{L}-I_{d}-\frac{V_{d}}{R_{\mathrm{sh}_{\text {array }}}},
\end{aligned}
$$

where $I_{d}$ is diode current, $V_{d}$ is the diode voltage, $I_{o}$ is the diode saturation current, $n I$ is diode ideality factor, $k$ is Boltzmann constant $\left(1.3806 e-23 \mathrm{~J} \cdot \mathrm{K}^{-1}\right), q$ is electron charge $(1.6022 e-19 \mathrm{C}), T$ is cell temperature $(\mathrm{K})$, and $N$ cell is the number of cells connected in series in a module.

3.2. Maximum Power Point Tracker Model. The maximum output power of PV array changes according to its operating temperature and solar irradiance. The output power of the PV array correlates to the outlet voltage of the PV array; the maximum output power of the PV array can be tracked through changing its outlet voltage. A number of MPPT algorithms are available in literature (e.g., [9]). The detailed system is shown in Figure 11.

Figure 11 shows that the output voltage of the PV array is changed by a boost converter. The output voltage of the boost 


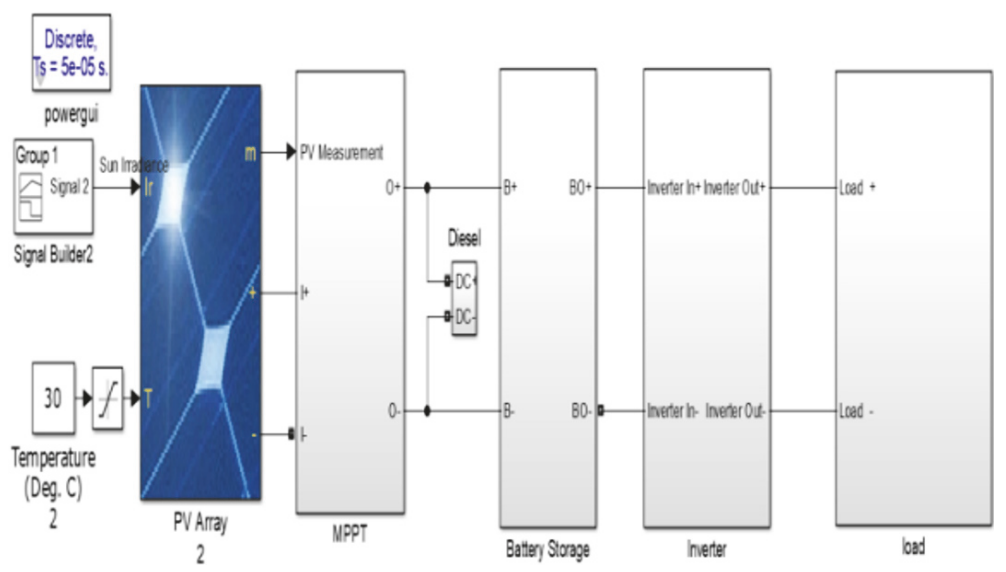

Figure 10: Overall system model.

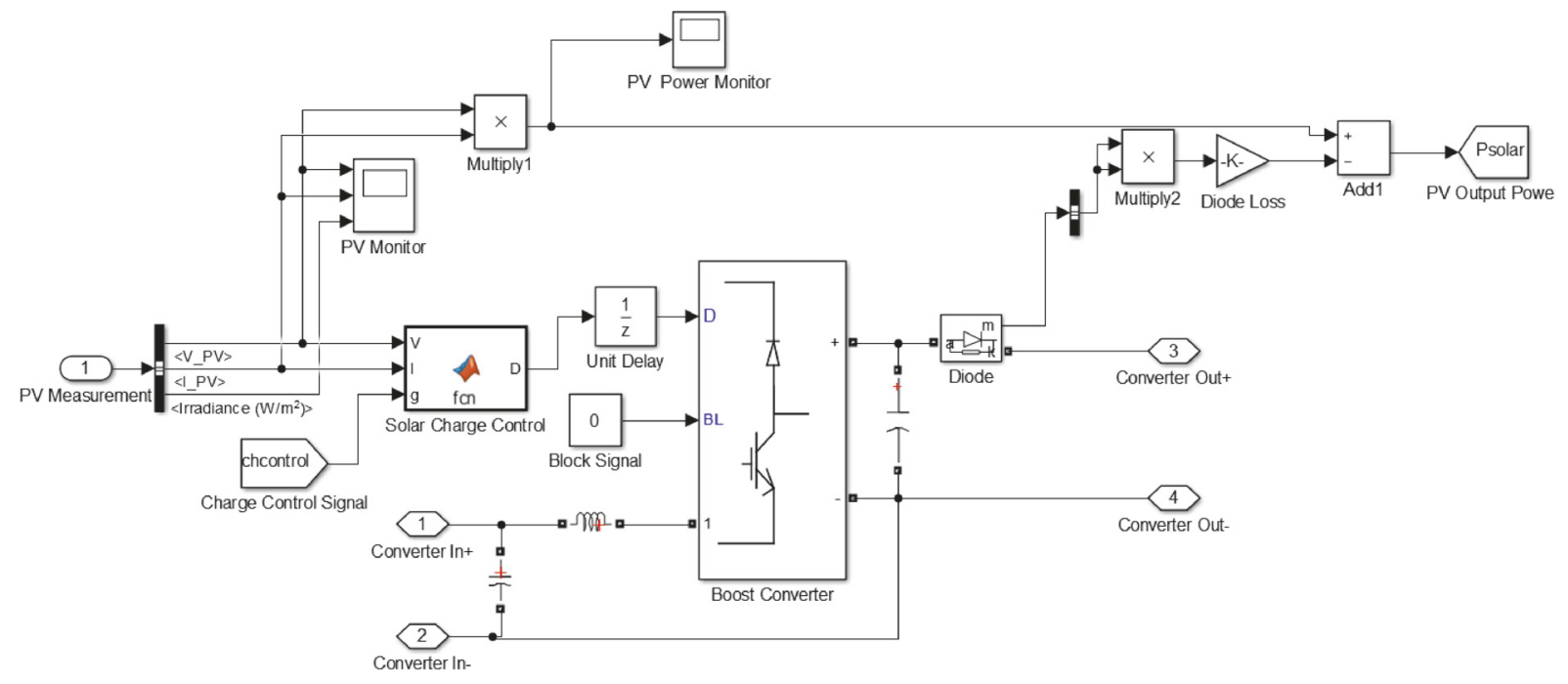

Figure 11: Maximum Power Point Tracker model.

converter is controlled by a function that changes the duty cycle of the converter according to the output current and voltage of the PV array. The relation between output voltage and duty cycle of the boost converter is shown as follows [7]:

$$
V_{\text {out }}=\frac{V_{\text {in }}}{1-\text { Duty }} \text {. }
$$

The adopted MPPT algorithm is simplified incremental conductance method with charge control function of the battery storage. When charge control signal is off, the output value of the duty cycle depends on the value of $V \mathrm{~d} I+I \mathrm{~d} V$. If the value is positive, the duty cycle will be increased; if the value is negative, the duty cycle will be decreased; if the value is zero, the duty cycle remains unchanged. When the charge control signal is off, the duty cycle will be switched to a value corresponding to minimum PV output. The algorithm is shown in Figure 12.
In order to decrease the ripple of the output current and voltage of the boost converter, the values of input inductance and output capacitor are calculated as follows [7]:

$$
\begin{aligned}
L & =\frac{V_{\text {in }}\left(V_{\text {out }}-V_{\text {in }}\right)}{\Delta I_{l} f_{s} V_{\text {out }}} \\
\Delta I_{l} & =\frac{(0.2 \sim 0.4) f_{s} V_{\text {out }}}{V_{\text {in }}} \\
\Delta V_{\text {PVmppt }} & =0.05 V_{\mathrm{mppt}} \\
\Delta V_{\text {PVmppt }} & =\frac{P_{\mathrm{mppt}}}{2 f_{g} C_{\mathrm{dc}} V_{\mathrm{mppt}}},
\end{aligned}
$$

where $V_{\text {in }}$ is the typical input voltage; $V_{\text {out }}$ is the typical output voltage; $f_{s}$ is the minimum switching frequency of the converter; $\Delta I_{l}$ is estimated inductor ripple current; $f_{g}$ is the carrier frequency of the inverter; $C_{\mathrm{dc}}$ is the capacitor at the output of the converter; $P_{\mathrm{mppt}}$ is the maximum power of the 


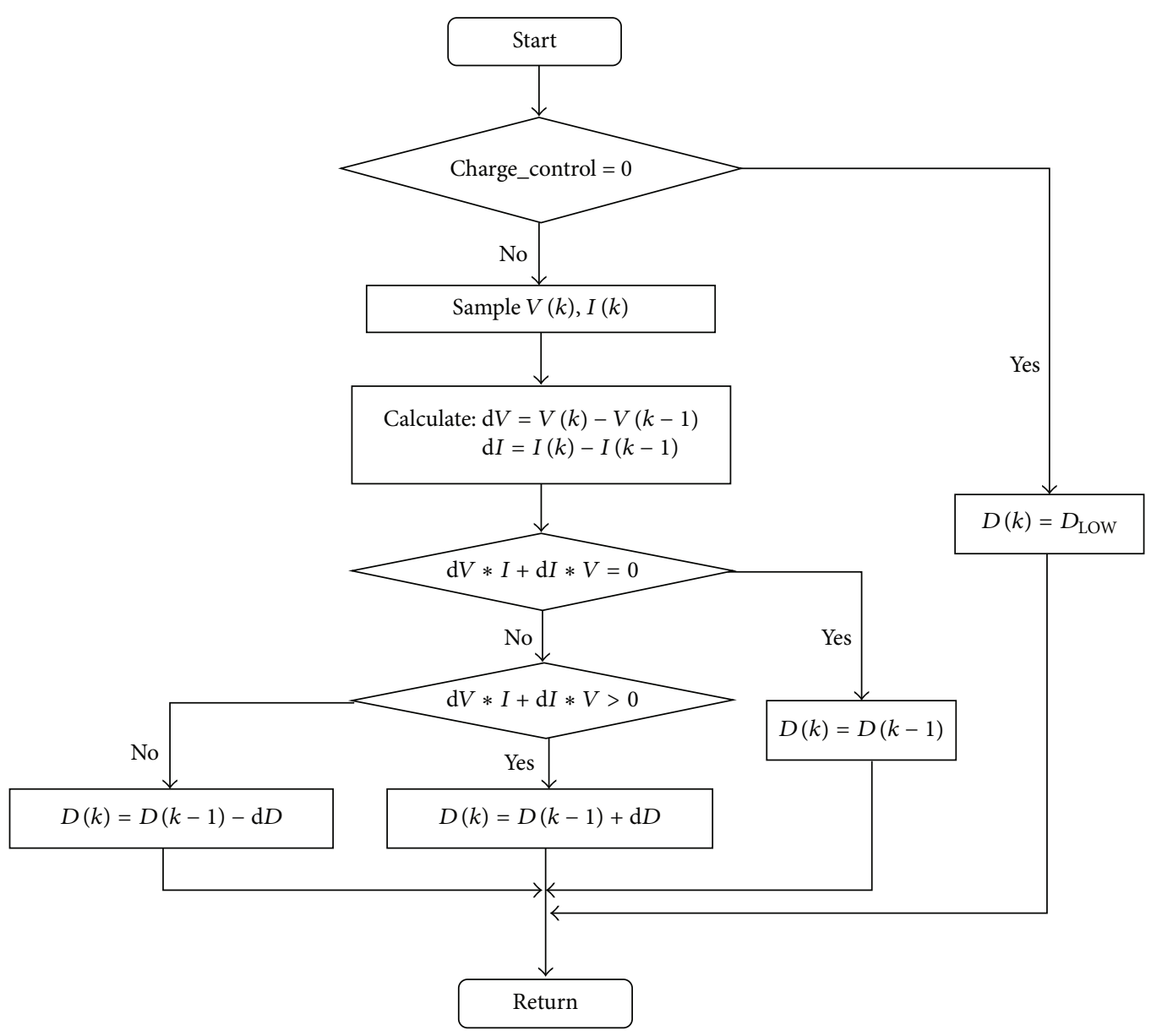

Figure 12: MPPT algorithm.

converter; $V_{\mathrm{mppt}}$ is the output voltage of the boost converter during maximum operation.

The measured PV power can be used for system monitoring and diesel generator control. In order to prevent the $\mathrm{PV}$ array from discharging the batteries during the night, a blocking diode is set at the output of the boost converter.

3.3. Battery Storage Model. The battery storage stores the energy from PV array and diesel generator when generated power is higher than the load. The battery discharges the energy when the generated power cannot supply the load. According to [10], the battery storage model is governed by 5 equations. The model is governed by only two equations, one for charging and the other for discharging, which are shown as follows [8]:

$$
\begin{aligned}
E_{\text {discharge }}= & E_{0}-\frac{K Q i^{*}}{Q-i_{t}}-\frac{K Q i_{t}}{Q-i_{t}} \\
& + \text { Laplace }^{-1}\left(\frac{A}{s / B i_{t}+1} \cdot 0\right)
\end{aligned}
$$

$$
\begin{aligned}
E_{\text {charge }}= & E_{0}-\frac{K Q i^{*}}{i_{t}+0.1 Q}-\frac{K Q i_{t}}{Q-i_{t}} \\
& + \text { Laplace }^{-1}\left(\frac{A}{s / B i_{t}+1} \cdot \frac{1}{s}\right),
\end{aligned}
$$

where $E_{0}$ is constant voltage $(\mathrm{V}), \mathrm{Q}$ is maximum battery capacity (Ah), $K$ is polarization constant, $i_{t}$ is extracted capacity (Ah), $A$ is exponential voltage $(\mathrm{V}), B$ is exponential capacity $(\mathrm{Ah})^{-1}$, and $i^{*}$ is low frequency current dynamics $(\mathrm{A})$.

This mathematic model describes the dynamics of the battery storage better than the algebra equations provided in [10]. Thus, the model from [11] is adopted. The detailed system of battery storage is shown in Figure 13.

Besides the battery storage, there is also a charge controller in this subsystem. This is to prevent the battery from overcharging. Commonly, the charge control is incorporated into the MPPT control and the diesel control system, which needs major adjustment of the MPPT algorithm and diesel controller. Rather than incorporating charge control into the MPPT and the diesel controller, an external charge controller is adopted to avoid the large adjustments. Once the battery 


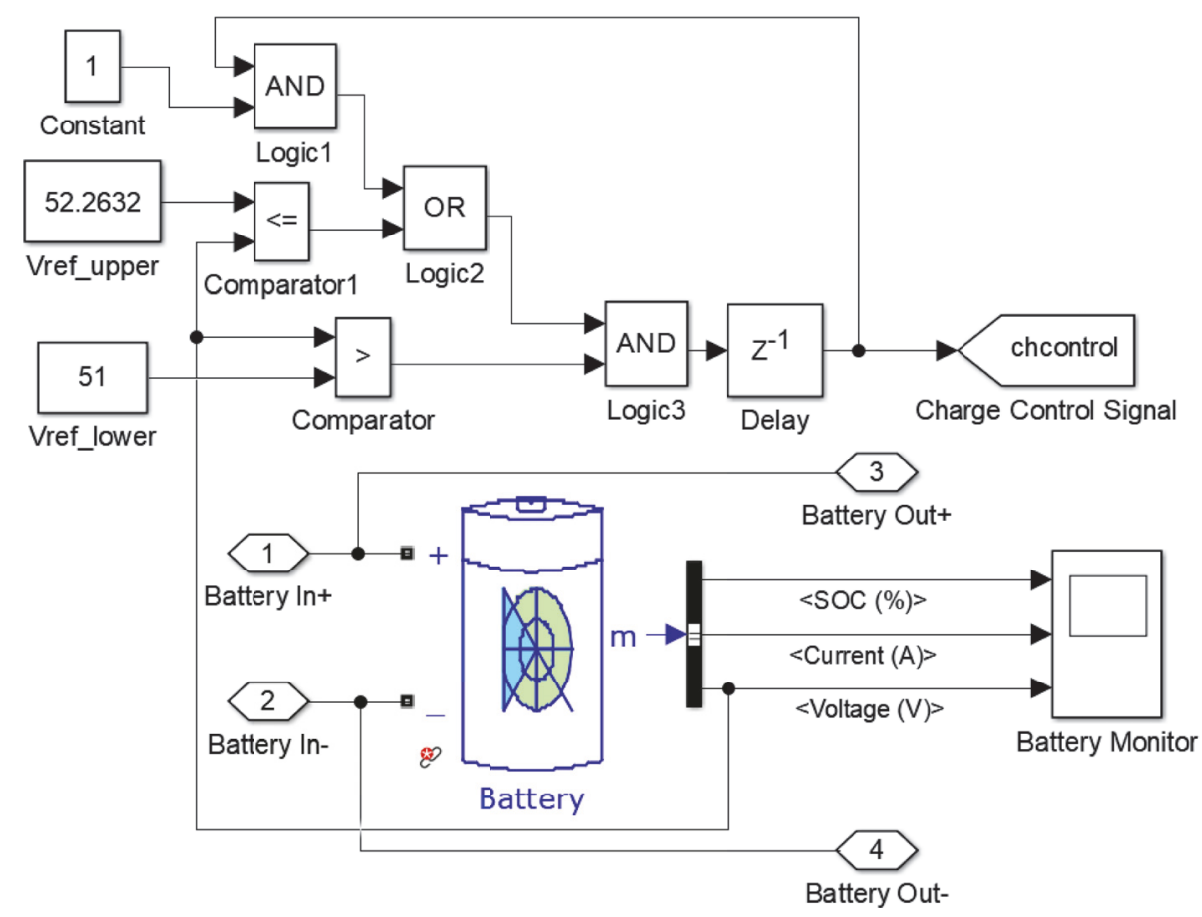

FIGURE 13: Battery storage model.

voltage reaches the high reference value, $52.2632 \mathrm{~V}$ (corresponding to $100 \%$ SOC with $200 \mathrm{~A}$ discharging current), the charge controller will output a control signal to shut down the diesel generator and switch the PV panel to low power output state until the battery storage voltage reaches the lower reference value, $51 \mathrm{~V}$ (corresponding to $99.96 \%$ SOC with 200 A discharging current). If the charge controller is a switch at the input of the battery storage, which opens when the battery storage voltage reaches $52.2632 \mathrm{~V}$, the power output of the PV array will oscillate within $\pm 13 \mathrm{~kW}$. Because of the onoff control of the diesel generator (shown in Section 3.4) and the self-switch-off function of the battery model, the device to prevent the battery from overdischarging is not needed in this system.

3.4. Diesel Generator. When the power generated by the PV panel is lower than the load power, the battery storage capacity will decrease. To prevent the battery from overdischarging, the diesel generator should be put into operation. The most common used generator is AC generator because of no commutator, but, for less power oscillation, a DC generator is adopted. Its mathematic model is shown as follows [11]:

$$
\begin{aligned}
\frac{\mathrm{d} i_{a}}{\mathrm{~d} t} & =-\frac{r_{a} i_{a}}{L_{A A}}-\frac{k_{v} \omega_{r}}{L_{A A}}+\frac{v_{a}}{L_{A A}} \\
\frac{\mathrm{d} \omega_{r}}{\mathrm{~d} t} & =\frac{k_{v} i_{a}}{J}-\frac{B_{m} \omega_{r}}{J}-\frac{T_{L}}{J},
\end{aligned}
$$

where $i_{a}$ is the armature current (A), $\omega_{r}$ is the rotational speed of the rotor $(\mathrm{rad} / \mathrm{s}), J$ is the total inertia $\left(\mathrm{kg} \cdot \mathrm{m}^{2}\right)$, $B_{m}$ is the viscous friction coefficient $(\mathrm{N} \cdot \mathrm{m} \cdot \mathrm{s}), T_{L}$ is the load torque $(\mathrm{N} \cdot \mathrm{m}), r_{a}$ is the resistance of the armature, $L_{A A}$ is the inductance of the armature $(\mathrm{H})$, and $k_{v}$ is the open-circuit voltage per speed constant $(\mathrm{V} / \mathrm{rpm})$. The detailed model of the diesel generator is shown in Figure 14.

It can be seen from Figure 14 that the generator model is a permanent magnet DC machine. The on-off control is realized by putting the signals of the charge controller and the comparison of the PV output power and the load power in series. When the charge control signal is on, if the power generated by PV array is lower than the load power, the generator will be started; otherwise, the generator will be switched off. When the charge control signal is off, the generator will be switched off regardless of the comparison result. In order to reach the rated output power of the generator steadily and robustly, a PI controller is used at the torque input. In order to keep the generator operating at the generator mode during its starting, an IGBT is used. Since the IGBT is unidirectional, the DC machine cannot operate at the motor mode. Single IGBT is not reliable during high power operation $(8 \mathrm{~kW})$, so a soft starter is used. As it is shown in Figure 14, once the power through the IGBT is higher than the reference value, $10 \mathrm{~W}$ (equivalent to $0.2 \mathrm{~A}$ ), the switch will be closed. Since the current through the switch is positive at this movement, the IGBT will be switched off. Once the output power decreases below the reference value $(10 \mathrm{~W})$, the switch will be switched off. The generator will stop supply. This also can prevent the large transients caused by the sudden circuit break during the full load operation of the diesel generator.

3.5. Inverter. The inverter transforms the $\mathrm{DC}$ power into single-phase AC power to supply the load. The detailed inverter model is shown in Figure 15. 


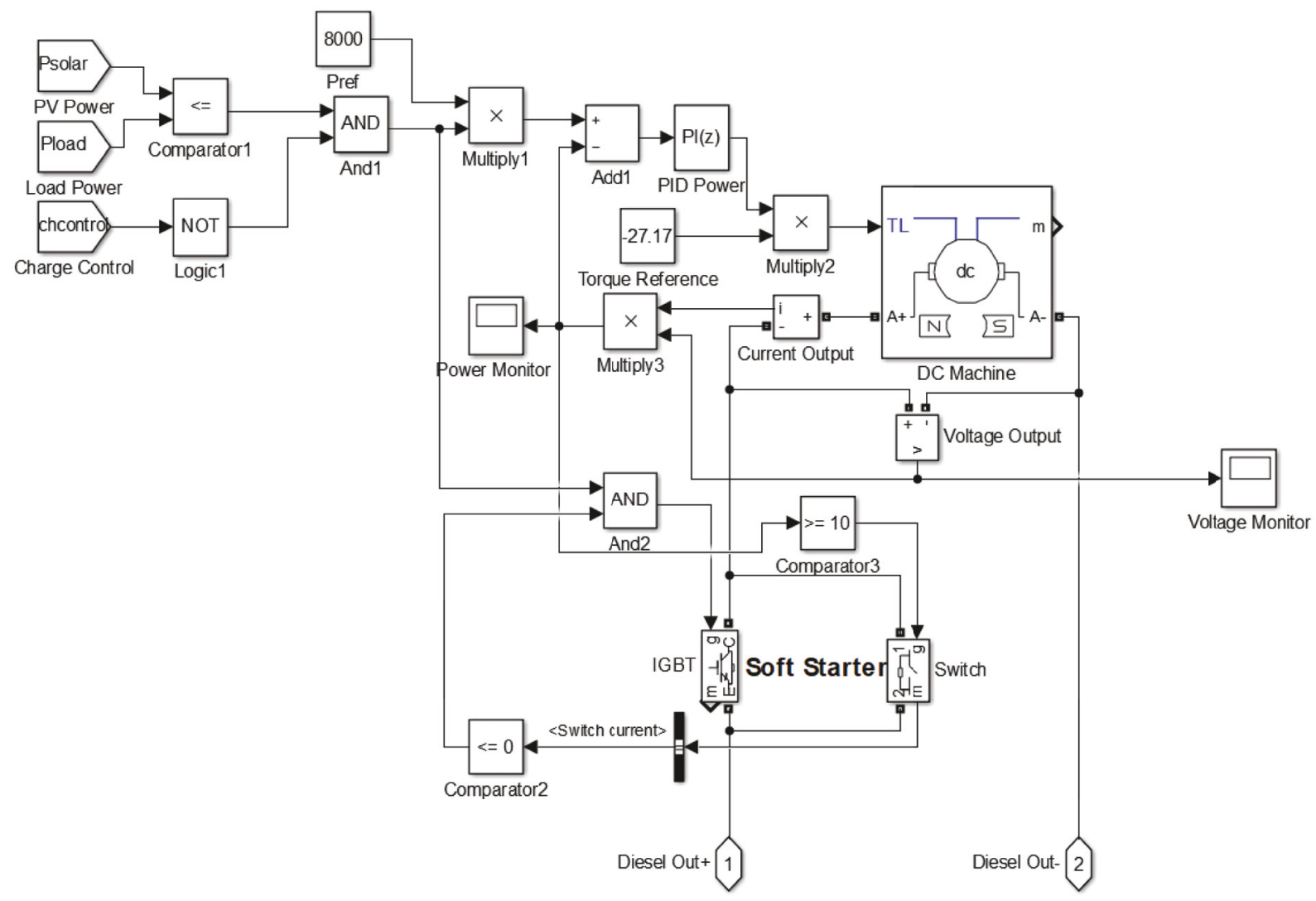

FIGURE 14: Diesel generator model.

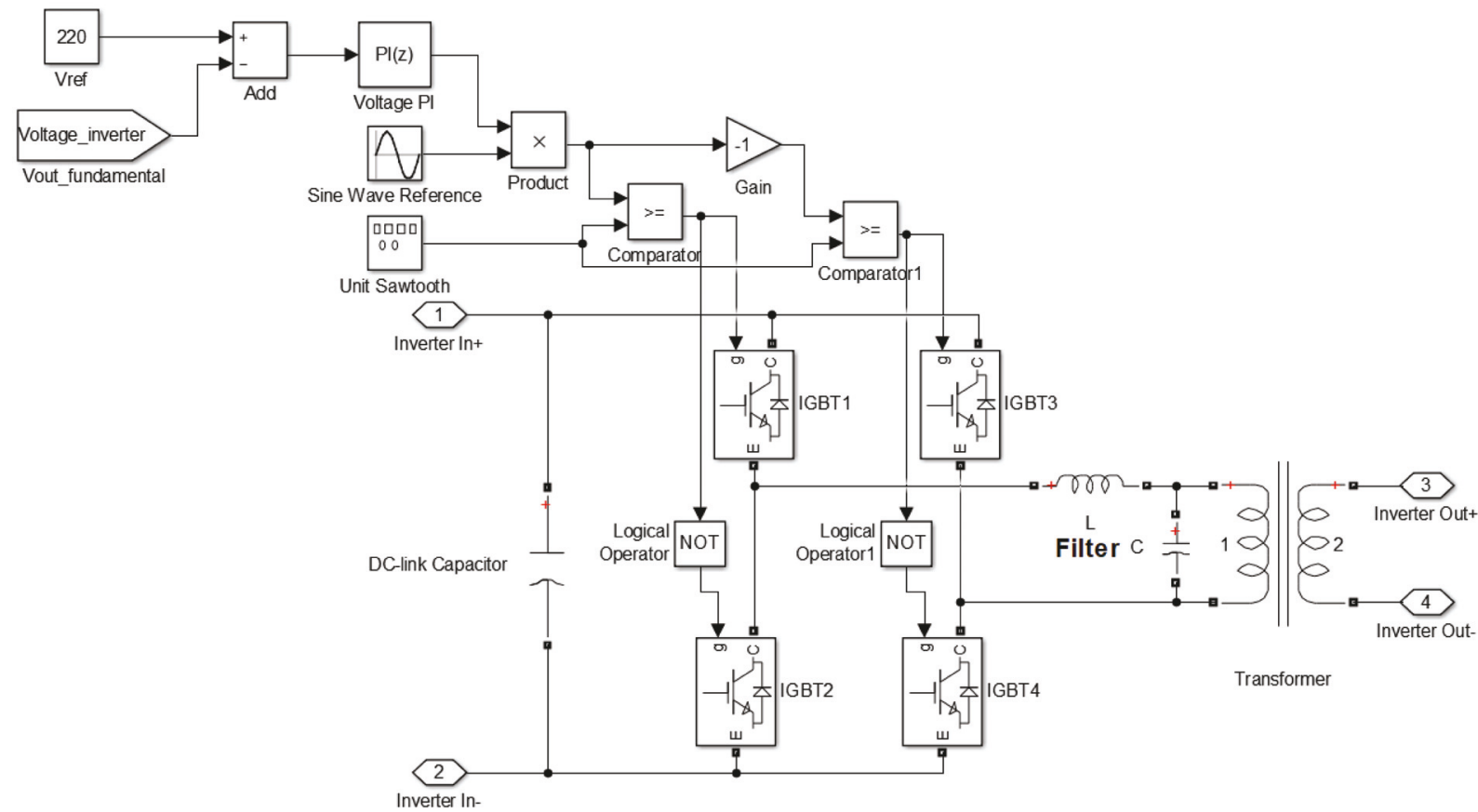

FIgURE 15: Inverter model. 
Figure 15 shows that the whole inverter model is constituted by four IGBT/diode devices, one LC filter, and one transformer. It also shows that the IGBTs are controlled by the unipolar pulse width modulation. This modulation technique cancels the harmonics with switching frequency of the inverter. To ensure a steady voltage output of the inverter, a closed-loop voltage control is used [12]. Compared to the voltage control of the fundamental wave of the load voltage in [12], the rms value of the fundamental load voltage is controlled in this research. The error between the measured fundamental load voltage (rms) and the reference value is sent to the PI controller. The output of the PI controller multiplies the sine wave and then compares with the sawtooth carrier signal, generating PWM signals to control the IGBTs. The LC filter behind the inverter is used to filter the harmonics with twice switching frequency of the AC output. The calculations of the inductance and capacitor are shown as follows [13]:

$$
\begin{aligned}
L & =\frac{V_{\mathrm{dc}}}{8 \Delta I_{\text {ripple.max }} f_{\mathrm{sw}}} \\
C_{f} & =\frac{\alpha P_{\text {rated }}}{2 \pi f_{\text {line }} V_{\text {rate }}^{2}},
\end{aligned}
$$

where $\Delta I_{\text {ripplemax }}$ is $20 \%$ of the rated current; $f_{\text {sw }}$ is twice of the frequency of the sawtooth carrier, since the harmonics in modulation frequency is canceled by the unipolar modulation [14]; $\alpha$ is the reactive power factor, which is less than $5 \%$. Since the value of the DC bus is $48 \sim 52.26 \mathrm{~V}$, the maximum line voltage after the filter, $V_{\text {rate }}$, is $48 \sim 52.26 \mathrm{~V}$. The transformer following the filter then boosts up the voltage to $220 \mathrm{~V}$ for AC applications.

3.6. Load Model. There are three cases in this model. The first one is the maximum load, corresponding to a $3.78 \Omega$ resistor, the second is the minimum load, corresponding to a $17.22 \Omega$ resistor, and the last case is the zero load, corresponding to a $10^{7} \Omega$ resistor. The detailed model is shown in Figure 16.

The phase-locked loop devices in Figure 16 are used to filter the fundamental voltage and current in order to monitor the load and control the inverter. The calculated power is to control the diesel generator.

\section{Simulation Results}

There are three cases.

4.1. Maximum Load with a Dip of Solar Irradiance and $50 \%$ State of Charge. This case simulates the operation of the hybrid power system under maximum load, where maximum pump load is $12.88 \mathrm{~kW}$. When the shadow of cloud passing through the PV array, the solar irradiance drops from $1000 \mathrm{~W} / \mathrm{m}^{2}$ to $500 \mathrm{~W} / \mathrm{m}^{2}$ from 10 seconds to 25 seconds and rises back to $1000 \mathrm{~W} / \mathrm{m}^{2}$ from 25 seconds to 40 seconds. Accordingly, the power output from the PV array is in the same form as the solar irradiance. The result of the power output of the PV array in this case is shown in Figure 17.

Figure 19 shows that the commissioning of the diesel generator around 3 seconds charges the battery storage and increases the voltage of the battery storage. Thus, the power output of the PV array starts to increase simultaneously.
It shows that the maximum power output of the PV array under maximum solar irradiance input is around $6500 \mathrm{~W}$. This is less than the maximum power output of the PV array, $13.32 \mathrm{~kW}$. The reason for this is that the output voltage of the $\mathrm{PV}$ array is firmly controlled by the battery storage. Since the output power of the PV array is less than the maximum load power $12.88 \mathrm{~kW}$, the diesel generator is started, supplying the battery and the load during the whole simulation. The power output of the diesel generator is shown in Figure 18.

The total generated power of the system is about $17 \mathrm{~kW}$. This is higher than the maximum load, so the battery storage is charged after the diesel is fully started (about 3 seconds). Thus, the state of charge and voltage of the battery storage start to increase at the same time. The simulation results of the voltage of the battery storage in this case are shown in Figure 19.

Although the magnitude of DC voltage changes during the simulation, the fundamental load voltage is basically maintained at $220 \mathrm{~V}$ due to the close-loop control of the modulation index. This is shown in Figure 20.

Accordingly, the power of the AC load is steadily maintained around $12.88 \mathrm{~kW}$ because of this stable fundamental load voltage.

4.2. Average Load with Increasing Solar Irradiance and $50 \%$ State of Charge. This case simulates the operation of the hybrid power system under average load $(2810 \mathrm{~W})$, when solar irradiance increases from $100 \mathrm{~W} / \mathrm{m}^{2}$ to $1000 \mathrm{~W} / \mathrm{m}^{2}$ during the simulation. In accordance with the solar irradiance, the power output of the PV array in this case is shown in Figure 21.

Similar to the first case, there is a ramp starting around 3 seconds. It also can be seen from Figure 21 that the power output of the PV array reaches the average load around 10 seconds. This time is also the time when the diesel generator starts to shut down. When the power passing through the switch is below $10 \mathrm{~W}$, the switch is closed. The power output of the diesel generator in this case is shown in Figure 22.

Similar to the 1st case, the battery begins to get charged around 3 seconds when the diesel generator is fully started. However, after 10 seconds, when the diesel generator starts to shut down, the increasing speed of the voltage of the battery storage starts to be slow because of the decreased power input. The battery storage voltage in this case is shown in Figure 23.

The same as the 1st case, the fundamental load voltage is steadily maintained at $220 \mathrm{~V}$, and thus load power is maintained at $2810 \mathrm{~W}$. The result of the fundamental load voltage is shown in Figure 24.

4.3. Maximum Solar Irradiation with Average Load and $99.3 \%$ State of Charge of the Battery Storage. This case is to check whether the system can stop charging the battery storage and maintain a steady SOC, when the battery storage SOC is close to $100 \%$, and the power generated by PV array is larger than the load power.

The simulation results of the power outputs of the PV array and the diesel generator and the battery storage voltage are shown in Figures 25, 27, and 26, respectively. 


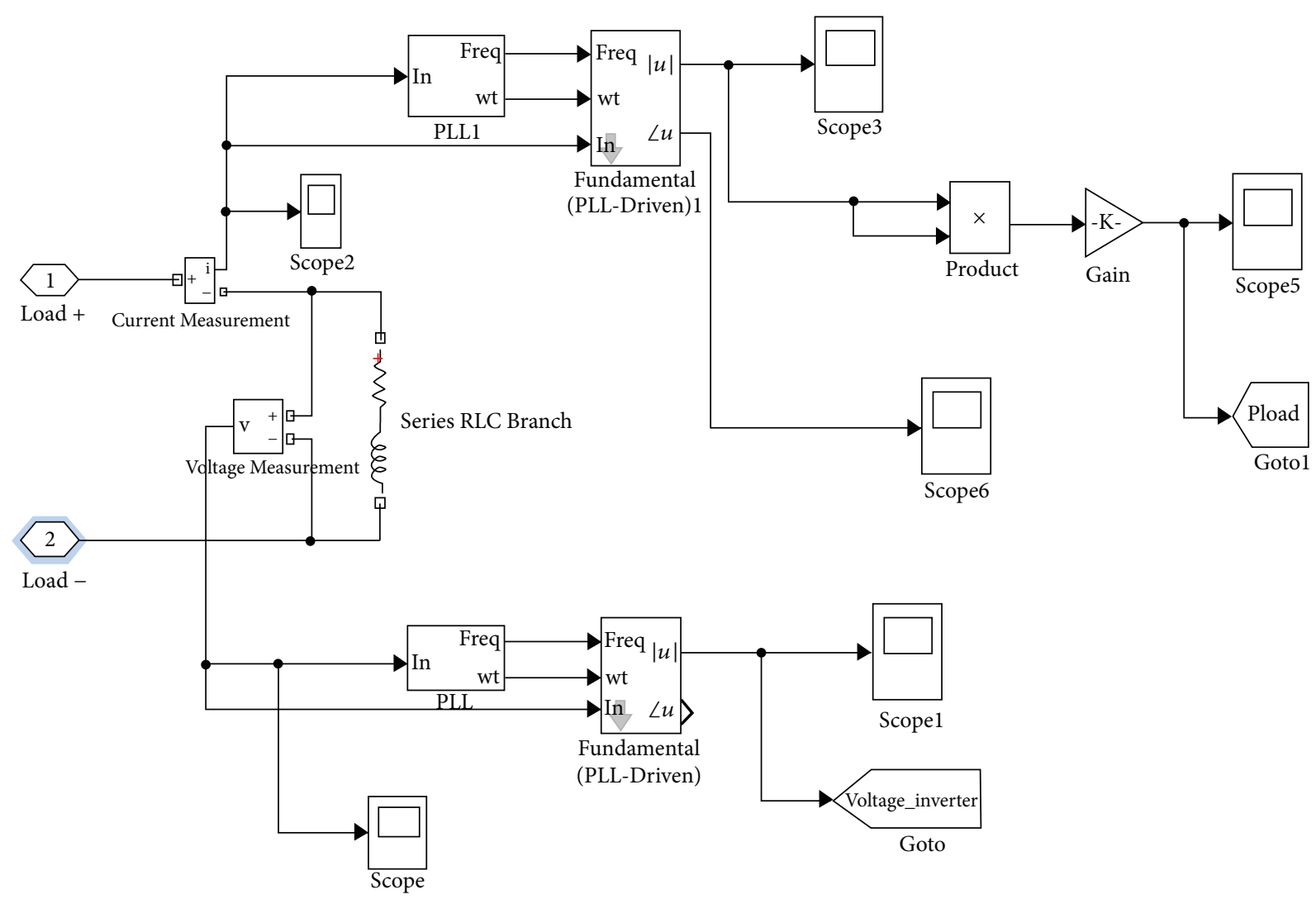

Figure 16: Load model.

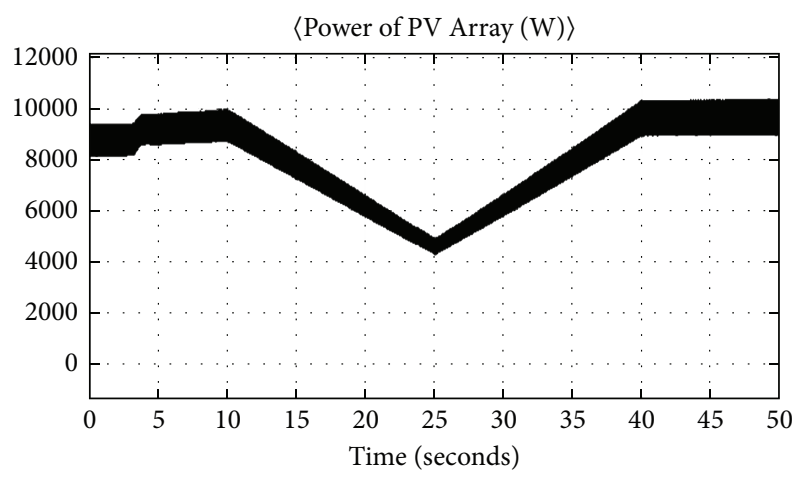

FIGURE 17: PV array power output in the 1st case.

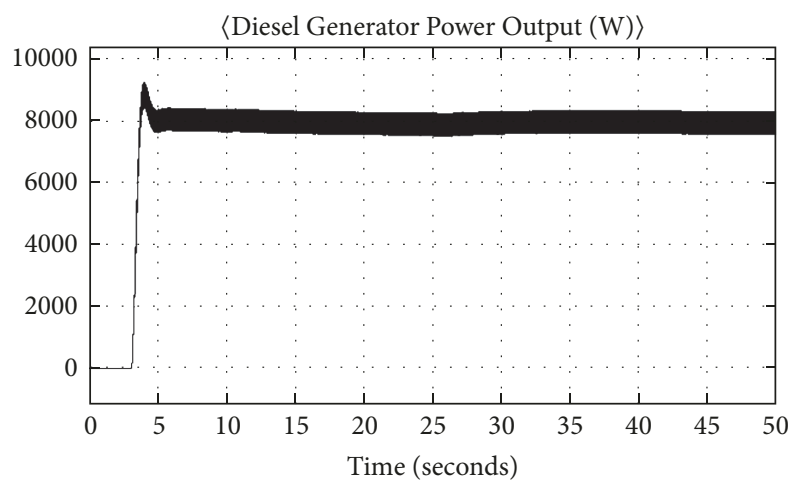

FIGURE 18: Diesel generator power output in the 1st case.

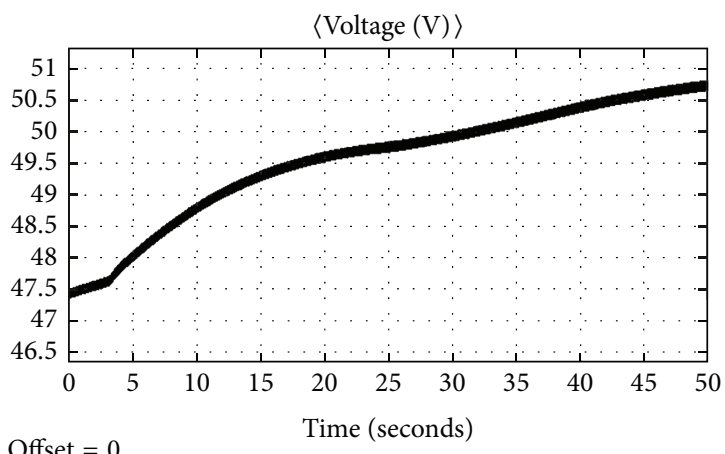

Figure 19: Battery voltage in the 1st case.

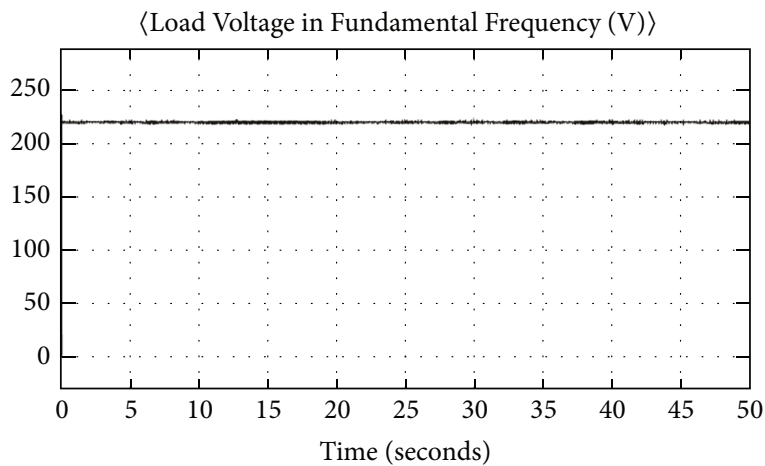

Figure 20: Fundamental load voltage in the 1st case. 


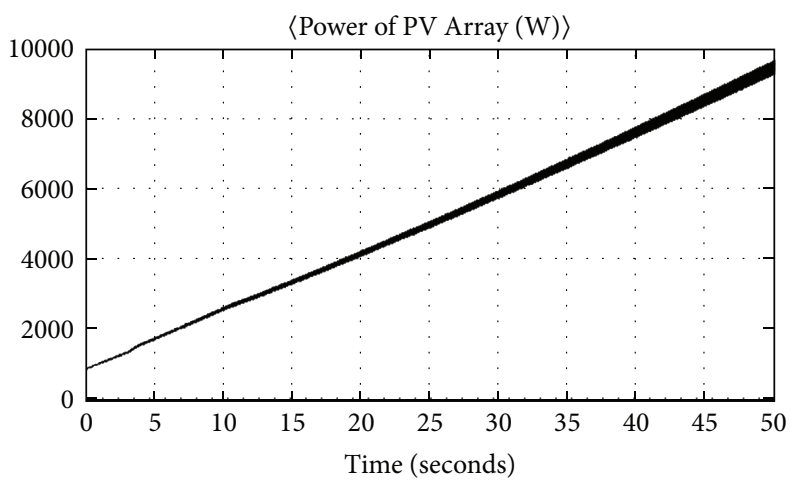

FIGURE 21: PV array power output in 2nd case.

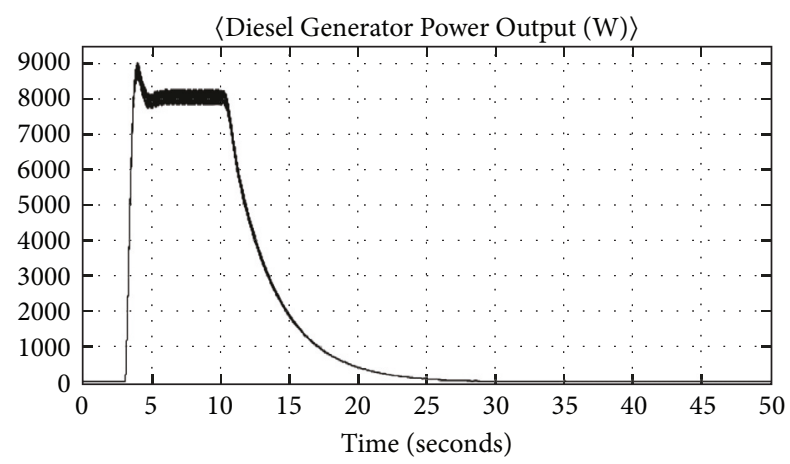

Figure 22: Diesel generator power output in the 2nd case.

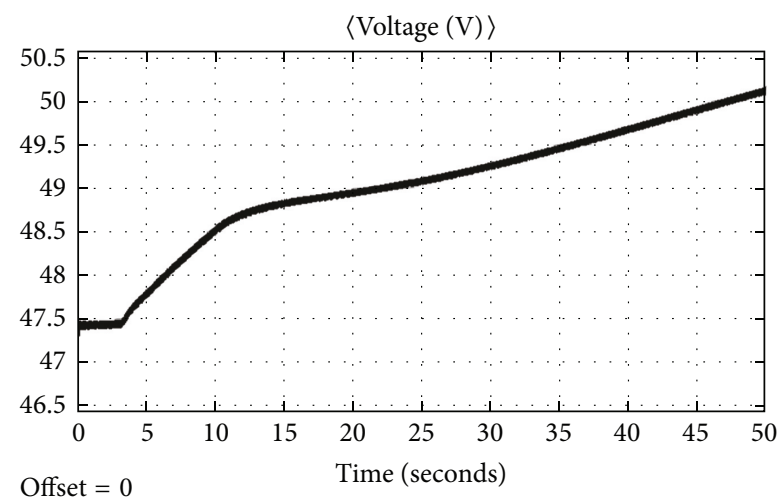

FIGURE 23: Battery storage voltage in the 2nd case.

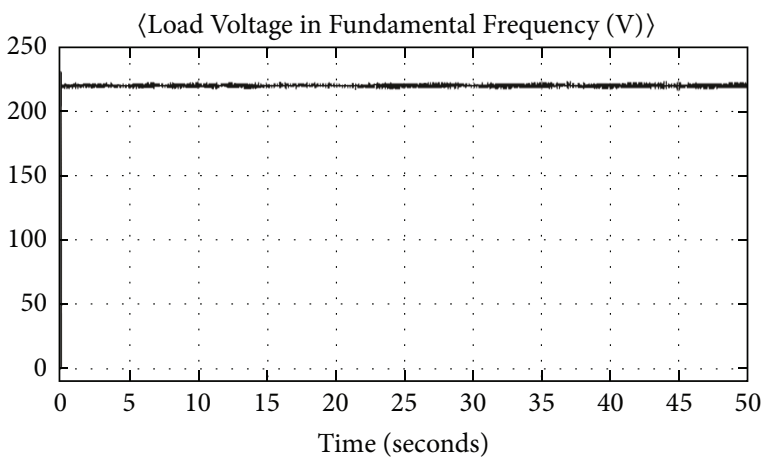

FIGURE 24: Fundamental load voltage in the 2nd case.

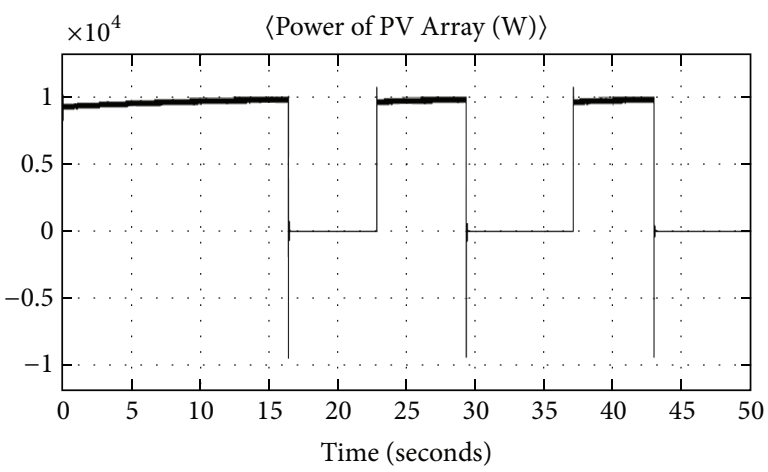

Figure 25: PV array power output in the 3rd case.

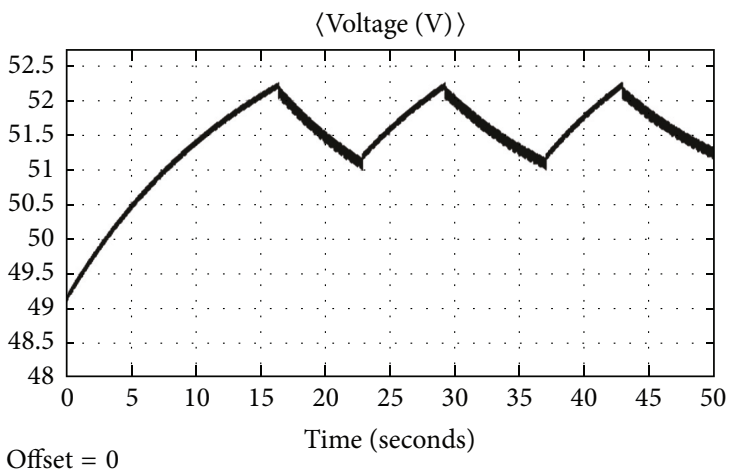

FIGURE 26: Battery storage voltage in the 3rd case.

Figure 26 shows that the battery storage stops charging and starts discharging three times at 16.46, 22.87, and 42.96 seconds, when the battery storage voltage reaches the high reference value $(52.2632 \mathrm{~V})$. At the same time, Figure 25 shows that the PV array stops working with high power output $(9100 \mathrm{~W})$ and starts to work at a low power output $(50 \mathrm{~W})$. Figure 27 shows that the diesel begins to start up when the PV array starts working with low power output and shuts down when the PV array starts working with high power output. Figure 26 shows that the battery storage stops discharging and starts charging at 22.86 and 37.07 seconds, when the battery voltage reaches the low reference value. Correspondingly, in Figure 25, the PV array switches its work state from the low power output to high power output, and in Figure 27 the diesel generator switches its work state from shutting down to starting up. Although the battery storage voltage oscillates during the simulation, the SOC is steadily maintained around $100 \%$. This is shown in Figure 28.

The fundamental load voltage, similar to the previous cases, is maintained at $220 \mathrm{~V}$ because of the closed-loop control of the inverter's modulation factor. This is shown in Figure 29.

\section{Conclusion}

This paper presented a design of a hybrid power system for a remote location in China. System sizing using Homer and load generation using BEopt are presented. Dynamic 


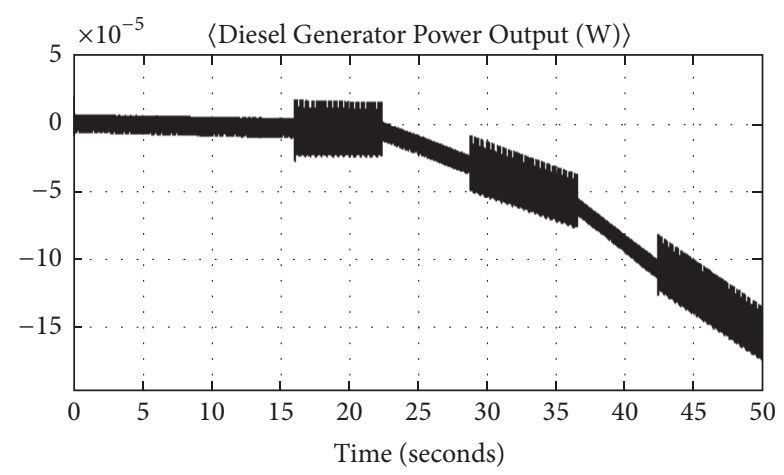

FIGURE 27: Diesel generator power output in the 3rd case.

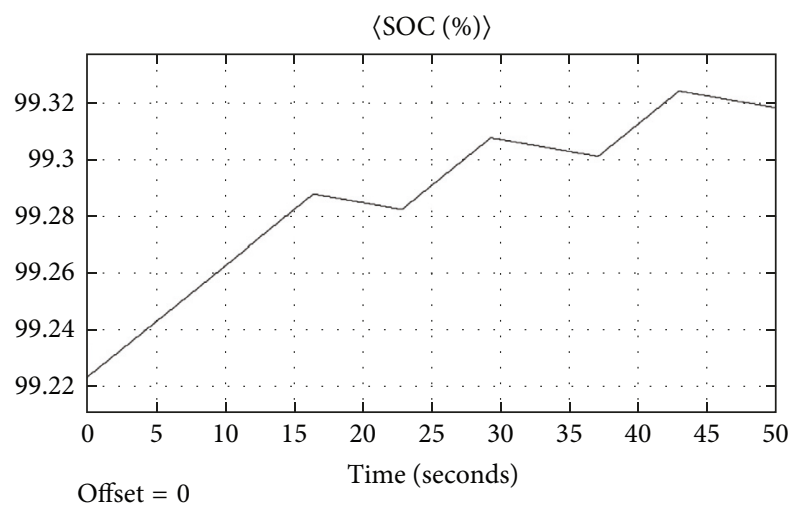

FIGURE 28: Battery storage SOC in the 3rd case.

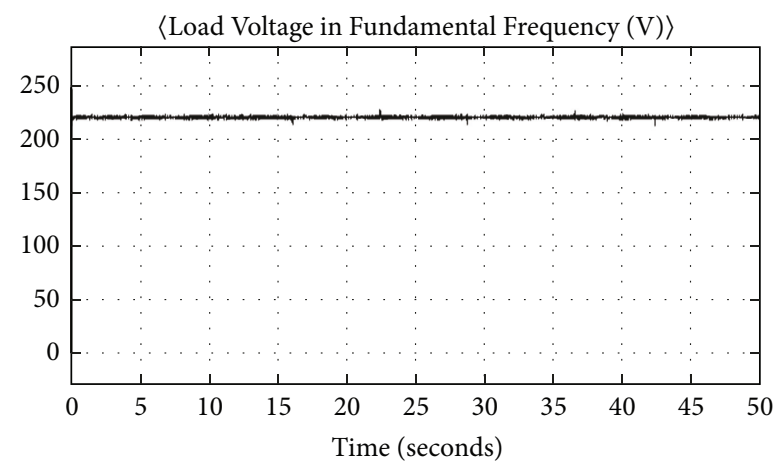

FIgURE 29: Fundamental load voltage in the 3rd case.

modeling is done using MATLAB/Simulink, and simulation is done for three residence cases. In all cases above, the fundamental load voltage is steadily controlled at $220 \mathrm{~V}$ under drastic changes of the load power and the total generated power (including the power from the PV array and diesel generator). This shows that the AC subsystem can be operated at a steady state during the system operation. The voltage of the DC subsystem (battery storage voltage) is maintained in a reasonable domain between $47.1268 \mathrm{~V}$ and $52.2632 \mathrm{~V}$ during system operation. This is realized by the on-off control of the diesel generator and charge controller of the battery storage. The on-off control of the diesel generator prevents the excessive consumption of the diesel and the overdischarging of the battery storage, when the load power is larger than the PV generated power. The charge controller of the battery storage can prevent the battery storage from overcharging.

This research shows that the simplified incremental method in MPPT has the same performance as the P\&O method. Despite the DC voltage oscillation, the SOC of the battery storage is steadily maintained around $100 \%$, when the battery storage is nearly fully charged. The soft starter of the diesel generator prevents the system from the drastic impulse after switching off the diesel generator. The PID control of the fundamental load voltage (rms) guarantees a steady AC voltage output under changing DC input.

However, the diesel generator model is based on a DC generator with commutators. In reality, the commutators need to be constantly replaced and maintained. That will increase maintenance fees of the system. The charge controller leads to DC voltage oscillation when the battery storage is nearly fully charged. The rms value of the fundamental load voltage shows $\pm 2 \mathrm{~V}$ oscillation around $220 \mathrm{~V}$ because of the single-loop voltage control of the inverter.

For the future work, a more advanced charge controller needs to be developed to minimize the DC voltage oscillation. Based on a stable DC voltage, the generator model should be switched to a three-phase permanent magnetic AC generator with a three-phase diode rectifier. Then, a multiloop control system of the inverter is needed for more stable fundamental load voltage.

\section{Conflicts of Interest}

The authors of this manuscript declare that the devices and software applications used in this research were sorely selected on a professional basis. There is no direct financial relation whatsoever with the trademarks mentioned in this manuscript which might lead to conflicts of interest.

\section{Acknowledgments}

This research was funded by Gansu Liujiaxia Hydropower Co., Ltd. The authors would like to acknowledge all the support and help from friends, family, and Memorial University of Newfoundland.

\section{References}

[1] L.-Q. Liu, Z.-X. Wang, H.-Q. Zhang, and Y.-C. Xue, "Solar energy development in China-A review," Renewable \& Sustainable Energy Reviews, vol. 14, no. 1, pp. 301-311, 2010.

[2] X. Changliang and S. Zhanfeng, "Wind energy in China: Current scenario and future perspectives," Renewable \& Sustainable Energy Reviews, vol. 13, no. 8, pp. 1966-1974, 2009.

[3] Z. Arthouros and L. Christine, Renewable Global Status Report, 2017.

[4] S. Kanteh Sakiliba, A. Sani Hassan, J. Wu, E. Saja Sanneh, and S. Ademi, "Assessment of Stand-Alone Residential Solar Photovoltaic Application in Sub-Saharan Africa: A Case Study of Gambia," Journal of Renewable Energy, vol. 2015, Article ID 640327, 10 pages, 2015. 
[5] S. Podder, R. S. Khan, and S. M. Alam Mohon, "The Technical and Economic Study of Solar-Wind Hybrid Energy System in Coastal Area of Chittagong, Bangladesh," Journal of Renewable Energy, vol. 2015, Article ID 482543, 10 pages, 2015.

[6] V. A. Ani, "Feasibility and Optimal Design of a Stand-Alone Photovoltaic Energy System for the Orphanage," Journal of Renewable Energy, vol. 2014, Article ID 379729, 8 pages, 2014.

[7] H. Brigitte, "Basic Calculation of a Boost Converter's Power Stage," Instrument Application Report, SLVA372C, Tex, USA, November 2009.

[8] Mathworks ${ }^{\mathrm{TM}}$, "Simscape ${ }^{\mathrm{TM}}$ Power Systems ${ }^{\mathrm{TM}}$ Reference (Simscape $^{\mathrm{TM}}$ Components) (r2016a)," 2016, http://www.mathworks .com/help/releases/R2016a/pdf_doc/physmod/sps/sps_ref.pdf.

[9] Subiyanto, A. Mohamed, and M. A. Hannan, "Intelligent Photovoltaic Maximum Power Point Tracking Controller for Energy Enhancement in Renewable Energy System," Journal of Renewable Energy, vol. 2013, Article ID 901962, 9 pages, 2013.

[10] J. F. Manwell and J. G. McGowan, "Lead acid battery storage model for hybrid energy systems," Solar Energy, vol. 50, no. 5, pp. 399-405, 1993.

[11] P. C. Krause, O. Wasynczuk, and S. D. Sudhoff, Analysis of Electric Machinery and Drive Systems, Wiley, 2nd edition, 2002.

[12] W. Zhaoan, Power Electronics, 5th edition, 2009.

[13] M. Azzi and N. A. Rahim, "Design Analysis of Low-pass Passive Filter in Single-phase Grid-connected Transformerless Inverter," International Journal of Renewable Energy Research, vol. 1, pp. 25-31, 2011.

[14] N. Mohan, M. Tore, and P. William, Power Electronics: Converters, Applications and Design, 2nd edition, 1995. 

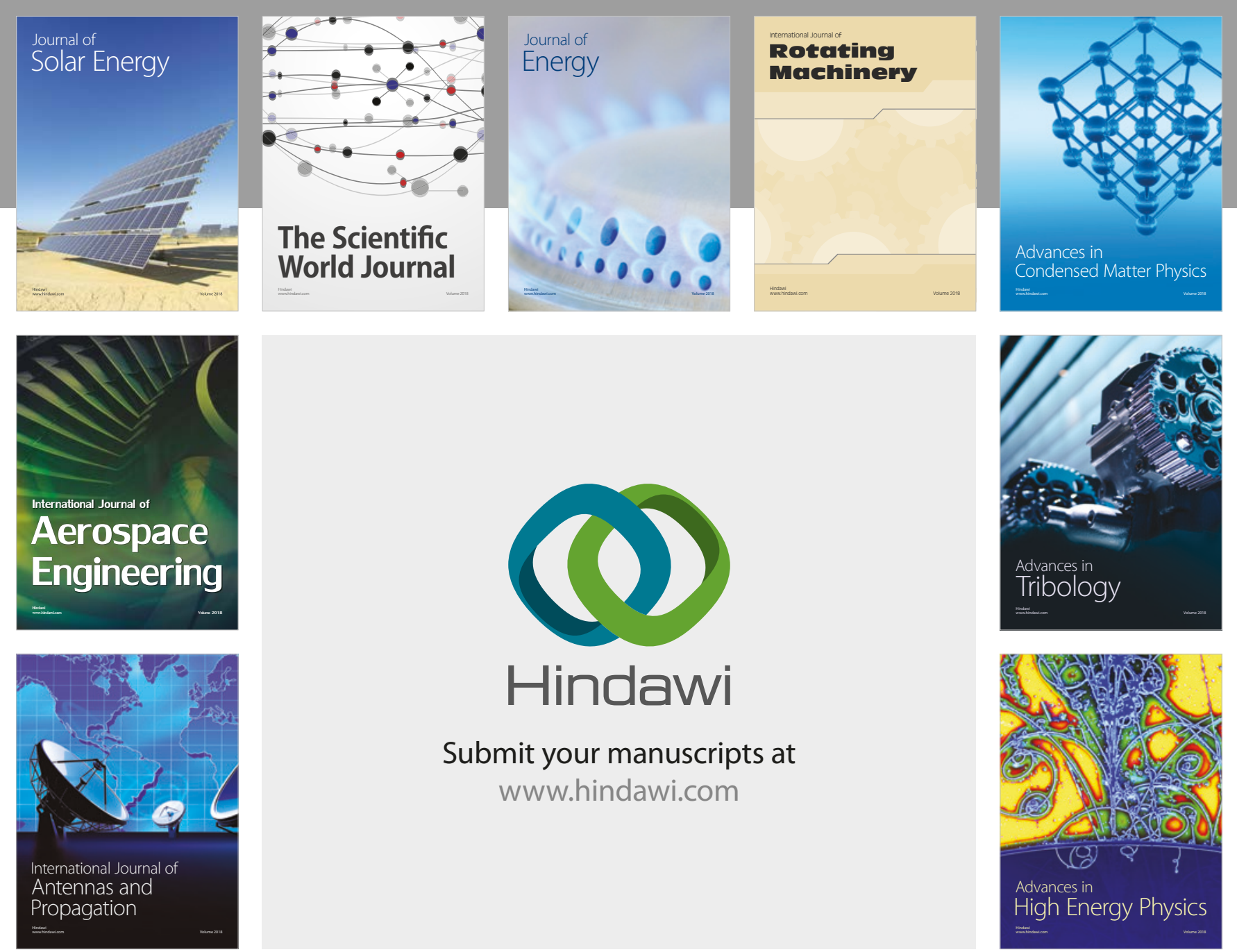

Submit your manuscripts at

www.hindawi.com
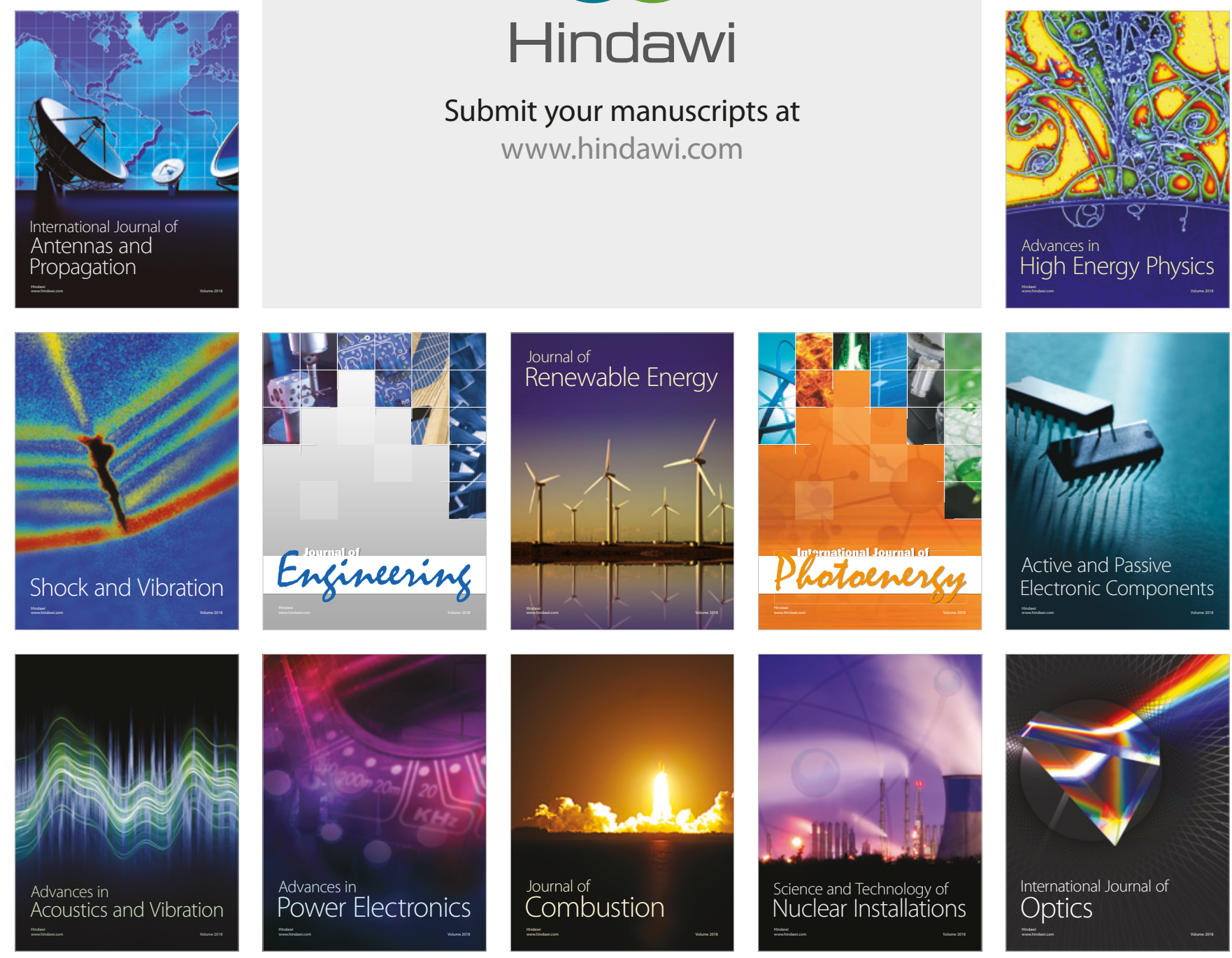